\title{
Expression of Vascular Notch Ligand Delta-Like 4 and Inflammatory Markers in Breast Cancer
}

\author{
Adrian M. Jubb, ${ }^{\star \dagger}$ Elizabeth J. Soilleux, ${ }^{*}$ \\ Helen Turley, ${ }^{*}$ Graham Steers, ${ }^{*}$ Andrew Parker, ${ }^{\ddagger}$ \\ Irene Low, ${ }^{\ddagger}$ Jennifer Blades, ${ }^{*} \mathrm{Ji}$-Liang $\mathrm{Li}^{\dagger}{ }^{\dagger}$ \\ Paul Allen, ${ }^{\neq}$Russell Leek, ${ }^{*}$ Irene Noguera-Troise, ${ }^{\S}$ \\ Kevin C. Gatter, ${ }^{*}$ Gavin Thurston, ${ }^{\S}$ \\ and Adrian L. Harris ${ }^{\dagger}$ \\ From the Nuffield Department of Clinical Laboratory Sciences," \\ and Molecular Oncology Laboratory, ${ }^{\dagger}$ Weatherall Institute of \\ Molecular Medicine, University of Oxford, Oxford, United \\ Kingdom; the Department of Cellular Pathology, John Radcliffe \\ Hospital, Oxford, United Kingdom; and Regeneron Research \\ Laboratories, ${ }^{\S}$ Tarrytown, New York
}

Delta-like ligand 4 (D114) is a Notch ligand that is predominantly expressed in the endothelium. Evidence from xenografts suggests that inhibiting D114 may overcome resistance to antivascular endothelial growth factor therapy. The aims of this study were to characterize the expression of 0114 in breast cancer and assess whether it is associated with inflammatory markers and prognosis. We examined 296 breast adenocarcinomas and 38 ductal carcinoma in situ tissues that were represented in tissue microarrays. Additional whole sections representing 10 breast adenocarcinomas, 10 normal breast tissues, and 16 angiosarcomas were included. Immunohistochemistry was then performed by using validated antibodies against D114, CD68, CD14, Dendritic Cell-Specific Intercellular adhesion molecule-3-Grabbing Non-integrin (DC-SIGN), CD123, neutrophil elastase, CD31, and carbonic anhydrase 9. D114 was selectively expressed by intratumoral endothelial cells in $73 \%$ to $100 \%$ of breast adenocarcinomas, $18 \%$ of in situ ductal carcinomas, and all lactating breast cases, but not normal nonlactating breast. High intensity of endothelial D114 expression was a statistically significant adverse prognostic factor in univariate $(P=0.002$ and $P=0.01)$ and multivariate analyses $(P=0.03$ and $P=0.04)$ of overall survival and relapse-free survival, respectively. Among the inflammatory markers, only CD68 and DC-SIGN were significant prognostic factors in univariate (but not multivariate) analyses of overall survival ( $P=0.01$ and 0.002 , respectively). In summary, Dll4 was expressed by endothelium associated with breast cancer cells. In these retrospective subset analyses, endothelial 114 expression was a statistically significant multivariate prognostic factor. (Am J Pathol 2010, 176:2019-2028; DOI: 10.2353/ajpath.2010.090908)

The growth of tumors requires angiogenesis, ${ }^{1}$ which is the consequence of increased expression of proangiogenic factors (for example, vascular endothelial growth factor $\mathrm{A}[\mathrm{VEGF}]^{2,3}$ ). The expression of VEGF in cancer is controlled by oncogenic signaling, ${ }^{4}$ hypoxia, ${ }^{5}$ and inflammatory cells. ${ }^{6}$ Although there is redundancy among proangiogenic factors in advanced cancer, ${ }^{7}$ many in vivo early stage cancer models show VEGF dependence. ${ }^{8,9}$

This observation has been exploited clinically, where the addition of an anti-VEGF antibody (bevacizumab) to first line taxane-based chemotherapy in recurrent/metastatic breast cancer was associated with prolongation of progression free survival (from a median of 5.9 to 11.8 months, $P<0.001) .{ }^{10}$ Nevertheless, there was no statistically significant overall survival benefit, and all patients in this trial eventually progressed after 4 years. ${ }^{10}$ Furthermore, a trial evaluating the addition of bevacizumab to capecitabine in previously treated metastatic/advanced breast cancer demonstrated only a $10.7 \%$ improvement in response rate and no survival benefit. ${ }^{11}$ To date, there are no validated clinical, radiological, or molecular biomarkers that can predict the survival benefit afforded by bevacizumab. ${ }^{12-15}$ Clinical data suggest that antiangiogenic drugs are active in breast cancer, ${ }^{10,16}$ and it may be necessary to identify biomarkers that predict their benefit.

Supported by Cancer Research United Kingdom, the Experimental Cancer Medicine Centre Network, the European Union Metoxia Framework, and the National Institute for Health Research Biomedical Research Centre, Oxford.

A.M.J. and E.J.S. contributed equally to this work.

Accepted for publication December 8, 2009

G.T. and I.N.-T. are employees of Regeneron Pharmaceuticals, Inc, which is developing a DII4-related therapy.

Supplemental material for this article can be found on http://ajp. amjpathol.org.

Address reprint requests to Professor Adrian L. Harris, M.B.B.S., M.A., F.R.C.P., Ph.D., F.Med.Sci., Molecular Oncology Laboratory, Cancer Research United Kingdom, Weatherall Institute of Molecular Medicine, University of Oxford, John Radcliffe Hospital, Headley Way, Headington, Oxford, OX3 9DS, United Kingdom. E-mail: aharris.lab@ imm.ox.ac.uk. 
Additional agents that disrupt functional angiogenesis have been developed to target tumors resistant to antiVEGF therapy. ${ }^{17,18}$ Recent studies have focused on Deltalike ligand 4 (D\|4), a ligand for Notch receptors 1, 3, and $4^{17-19}$ that is predominantly expressed by endothelial cells. ${ }^{17-19}$ Transgenic mice in which DII4 was replaced by a reporter gene showed that DII4 expression is restricted to large arteries during development. ${ }^{20,21}$ Furthermore, DII4 heterozygous knockout mice are reported to have defective arterial development ${ }^{22}$ and venous malformations. ${ }^{22}$

Experimental systems ${ }^{17,23,24}$ have shown that D\|4-Notch inhibition leads to increased sprouting and branching of vessels in association with gradients of VEGF. Conversely, VEGF blockade causes a reduction in DII4 expression and vessel sprouting. ${ }^{17,18,23-27}$ In addition, endothelial cells transfected with DII4 down-regulated VEGF receptors KDR and neuropilin1 and showed reduced proliferative and migratory responses to VEGF. ${ }^{28}$ The implication of this research is that D\|l4-Notch signaling regulates endothelial sprouting and branching to form functional vascular beds, under the control of VEGF and by autoregulation of VEGF signaling. ${ }^{23}$

Disruption of DII4 signaling by overexpression or inhibition of DII4 may impair angiogenesis, ${ }^{17,18}$ and blockade of DII4-Notch signaling results in an increased density of nonfunctional vasculature and is associated with a reduction in the growth of human tumor xenografts. ${ }^{17,18}$ Indeed, certain xenografts that are resistant to anti-VEGF therapy are reported to be sensitive to anti-D\|4, ${ }^{17,18,29}$ and combination treatment with anti-VEGF and anti-DII4 has additive inhibitory effects on tumor growth. ${ }^{18}$ Together these data provide a rationale to target DII4 in cancer and suggest that DII4 may have a role in mediating resistance to anti-VEGF therapies.

Besides direct vascular effects, Fung et $\mathrm{al}^{30}$ showed that DII4-Notch signaling in macrophages stimulates a proinflammatory response, which may be proangiogenic. ${ }^{6}$ Moreover, Shojaei et $\mathrm{al}^{31,32}$ have reported that bevacizumab resistance in certain preclinical in vivo cancer models is causally associated with tumor infiltration by myeloid cells.

The characterization of DII4 protein expression in human cancer is important for the rational design of clinical trials to test the safety and activity of anti-DII4 therapy. Defining the pattern of DII4 expression, in association with markers of inflammation, may identify subgroups with distinct clinical behavior and responses to treatment. The aims of this study were to characterize the in situ expression of DIl4 in breast cancer, to assess the association between DII4 and established markers of inflammation (CD68, CD14, neutrophil elastase, CD123, and Dendritic Cell-Specific Intercellular adhesion molecule-3-Grabbing Non-integrin [DCSIGN]) and hypoxia (carbonic anhydrase 9 [CA9]), and to determine the prognostic significance of these markers.

\section{Materials and Methods}

\section{Patients and Tissue Samples}

Formalin-fixed paraffin-embedded (FFPE) tissues were obtained for 296 sequential patients with breast adeno- carcinoma (surgery was performed between 1989 and 1998 at the John Radcliffe Hospital, Oxford, UK). Patients were treated with a wide local excision and postoperative radiotherapy or mastectomy with or without postoperative radiotherapy. Postoperative chemotherapy $\left(600 \mathrm{mg} / \mathrm{m}^{2}\right.$ cyclophosphamide, $40 \mathrm{mg} / \mathrm{m}^{2}$ methotrexate, and 600 $\mathrm{mg} / \mathrm{m}^{2} 5$-fluorouracil intravenously each on day 1 of a 21-day cycle $\times 6$ ) and hormonal therapy (tamoxifen 20 mg daily for 5 years) were offered according to local protocols. Demographic, pathological, and treatment details are provided in Supplemental Table S1 (see http:// ajp.amjpathol.org). Sample size was determined by the availability of tissue with clinicopathological data, survival follow-up, and ethical approval for research. Two cases had no survival data available. Follow-up data were correct as of January 2008, with a median follow-up time of 10 years, a median overall survival of 13.7 years, and a median relapse-free survival of 13.8 years. Estrogen receptor (ER) content was determined by using an enzymelinked immunosorbent assay technique (Abbott Laboratories, Abbott Park, IL). Tumors were considered positive when cytosolic ER levels were $>10 \mathrm{fmol} / \mathrm{mg}$ of total cytosolic protein. Receptor values were monitored by participation in the European Organization for Research and Treatment of Cancer (EORTC) quality control scheme. Human Epidermal growth factor Receptor 2 (HER2) status was assessed with the HercepTest (Dako, Carpinteria, CA).

Tissue microarrays (TMAs) were assembled as described previously ${ }^{33}$ with three replicate cores for each tumor. Tissue from 38 patients with breast ductal carcinoma in situ was also represented in TMAs for analysis. An additional 10 breast adenocarcinomas, five normal breast resections, five normal lactating breast tissues, seven breast angiosarcomas, and nine nonbreast angiosarcomas (five skin, one duodenal, one liver, one pleural, and one vaginal) were also collected (John Radcliffe Hospital) to investigate the expression of DII4 in whole sections.

Approval was obtained for the use of all human tissue from the local research ethics committee (C02.216). The National Cancer Institute's Reporting Recommendations for Tumor Marker Prognostic Studies criteria were used in the design, analysis, and interpretation of this research. ${ }^{34}$

\section{In Situ Hybridization}

A 727 base ${ }^{35}$ S-labeled ( ${ }^{35} \mathrm{~S}-U T P \quad 800 \mathrm{Ci} / \mathrm{mmol}$; PerkinElmer, Waltham, MA) antisense riboprobe $100 \%$ homologous to human DLL4 (position 2089 to 2815 of GenBank accession NM_019074.2) was generated by using T3 RNA polymerase (Promega, Southampton, UK) from a linearized blunt ended vector containing the above insert. Isotopic in situ hybridization, washes, and developing were performed by using previously described methods. ${ }^{35}$ In brief, FFPE tissue sections were deparaffinized in xylenes and rehydrated through graded alcohols. Deproteination was performed for 15 minutes at $37^{\circ} \mathrm{C}$ with $20 \mu \mathrm{g} / \mathrm{ml}$ proteinase K (Sigma-Aldrich, Gillingham, UK). Slides were air-dried before hybridization overnight at $55^{\circ} \mathrm{C}$. Posthybridization, a series of increasingly stringent washes were performed, and unhybridized probe was digested 
with $20 \mathrm{mg} / \mathrm{ml}$ RNase A (Sigma-Aldrich) for 60 minutes at $37^{\circ} \mathrm{C}$. Slides were then dehydrated through a gradient of alcohols, air-dried, and immersed in liquid film emulsion (GE Health care, Chalfont St Giles, UK) for 14 days, before they were developed and counterstained with H\&E. In situ hybridization for $\beta$-actin on a serial section was used as a positive control for mRNA integrity.

\section{Immunohistochemistry}

Immunohistochemistry for CD68 (clone KP1; Nuffield Department of Clinical Laboratory Sciences, University of Oxford, UK), ${ }^{36}$ CD14 (clone 223; Leica Microsystems, Newcastle-on-Tyne, UK), ${ }^{37}$ neutrophil elastase (clone NP57; Nuffield Department of Clinical Laboratory Sciences), ${ }^{38}$ DC-SIGN (clone DC28; R and D Systems, Minneapolis, MN), ${ }^{39}$ CD31 (clone JC/70a; Dako), ${ }^{36}$ CA9 (clone M75; a gift from Professor S. Pastorekova and Professor J. Pastorek, Institute of Virology, Slovak Academy of Sciences, Bratislava, Slovak Republic), ${ }^{40,41}$ CD123 (clone 7G3; BD Pharmingen, San Diego, CA), ${ }^{42}$ and DII4 (clone 242; Regeneron, Tarrytown, NY $)^{43}$ was performed either manually or by using a Bond Max immunostaining machine (Leica) as per the manufacturer's instructions with controls for all experiments (tonsil and/or placenta for inflammatory cell markers; renal cell carcinoma for CA9 and CD31; and renal cell carcinoma, normal kidney, FFPE human umbilical vein endothelial cell pellets, and FFPE U87 cell pellets transfected with empty vector or recombinant human $\mathrm{D} \| 4^{43}$ for D\|l4).

Immunohistochemistry for DII4 was performed by using an anti-DII4 monoclonal antibody (the variable regions of this antibody are fully human, and the $\mathrm{Fc}$-domain is mouse; clone 242) that binds to the extracellular domain of human DII4 (the epitope is in epidermal growth factor-like domains 3 to 5) and generated in Veloclmmune mice (Regeneron). In brief, antigen retrieval was performed in target retrieval solution (Dako) by using a Decloaking Chamber (Biocare Medical, Concord, CA). Sections were incubated for 16 hours at $4^{\circ} \mathrm{C}$ with the primary antibody at $1 \mu \mathrm{g} / \mathrm{ml}$. Bound antibody was labeled with Novolink polymer (Leica), visualized by using 2,3diaminobenzidine chromogen, and counterstained with hematoxylin.

Cores were scored as positive for CA9 if membranous/ cytoplasmic expression was observed in $>10 \%$ of epithelial cells. Inflammatory markers were scored on a semiquantitative scale, with negative cores scored 0 , cores with occasional positive inflammatory cells scored 1 , cores with 10 to 30 labeled inflammatory cells scored 2 , and cores with $>30$ labeled inflammatory cell infiltrate scored 3. CD31 was scored 0 in tumor cores if there were no vessels or $\leq 10$ individual vessel profiles in a core, or scored 1 if there were $>10$ profiles. Intensity of DII4 expression by the endothelium was scored on a semiquantitative scale by two pathologists, with negative cores scored 0 , cores with weak expression scored 1 , and cores with moderate/strong expression scored 2. The highest intensity score among replicate cores was used as the score for each patient. All assays and analyses were performed blind to the study endpoints.

\section{Statistics}

The $\chi^{2}$ test was used to evaluate associations between categorical variables. The false discovery rate controlling procedure (threshold, $P<0.05$ ) was used to eliminate spurious statistical associations as a result of multiple testing. ${ }^{44}$ All survival analyses refer to overall survival times, where death from any cause represents an event or relapse-free survival, where first relapse or death from any cause represents an event. The median and mean survival times within each subgroup were estimated from Kaplan-Meier curves. Patients were censored in survival analyses according to the date last seen by a doctor. For univariate and multivariate survival models, Cox regression analysis was used to identify prognostic factors. All statistically significant prognostic factors in univariate analyses were included in the multivariate model. All statistical analyses were performed with SPSS Statistics (version 16.0; SPSS, Chicago, IL). Two-sided $P$ values $<0.05$ were considered statistically significant. Cases with missing data were omitted from statistical analyses.

\section{Results}

\section{Frequency and Pattern of Expression}

Analyses of tumors from the 296 patients yielded informative data on 151 to 252 patients. Results were not available for the remaining cases in certain assays because of exhaustion of TMAs with repeated sectioning and loss of cores. However, all subsets analyzed were representative of the total patient population (Supplemental Table S1, see http://ajp.amjpathol.org).

The monoclonal antibody (clone 242) that specifically recognizes the extracellular domain of human DII4 did not stain U87 cells transfected with empty vector, but showed membranous and cytoplasmic staining in U87 cells transfected with recombinant human DII4 and untransfected human umbilical vein endothelial cells. ${ }^{43}$ Normal kidney did not express DII4, but endothelial cells in renal cell carcinoma showed endothelial expression of DII4, consistent with previous in situ hybridization results. ${ }^{43,45,46}$ CA9 and CD31 were expressed in tumor cells adjacent to areas of necrosis and the endothelium of the control renal cell carcinoma tissue, respectively. ${ }^{47,48}$ CD68 and CD14 were expressed predominantly by macrophages present within the germinal centers of control tonsil tissue. ${ }^{49,50}$ Neutrophil elastase was expressed exclusively by neutrophil polymorphs present within control inflamed tonsil tissue. ${ }^{38}$ DC-SIGN was expressed specifically by myeloid dendritic cells in control tonsil and Hofbauer cells (specialized placental macrophages) in placental tissue. ${ }^{37}$ CD123 was expressed by plasmacytoid dendritic cells in control tonsil tissue. ${ }^{51}$

In initial analyses of whole sections, in situ hybridization revealed selective expression of Dll4 by the endothelial component of intra- and peritumoral vessels, irrespective of their size and maturity (Supplemental Figure S1, see http://ajp.amjpathol.org). By immunohistochemistry, strongly positive cytoplasmic and 

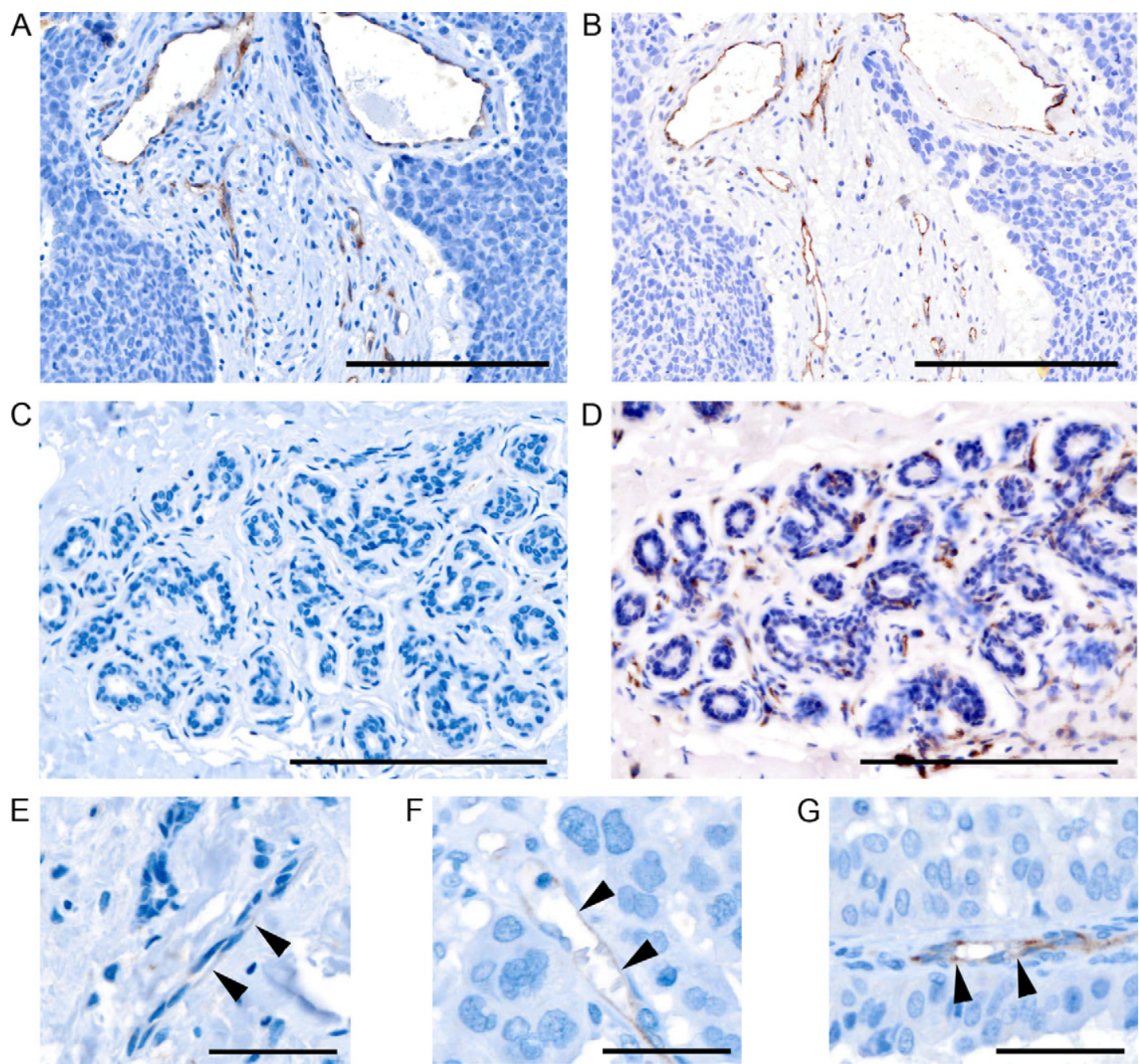

Figure 1. Membranous/cytoplasmic Dll4 expression (brown) in endothelium adjacent to breast cancer (A) with matching CD31 expression (B) is shown. Endothelium adjacent to normal breast does not express Dll4 by immunohistochemistry $(\mathbf{C})$, but is identified by CD31 $(\mathbf{D})$. Scale bar $=100 \mu \mathrm{m}$. Representative examples of Dll4 scoring in endothelial cells (arrowheads), scored $0(\mathbf{E}), 1(\mathbf{F})$, and $2(\mathbf{G})$ are shown. Scale bar $=25 \mu \mathrm{m}$.

membranous expression of Dll4 was observed in tumor associated endothelium in $100 \%$ (10 of 10) of invasive breast adenocarcinomas (Figure 1, A and B). No difference was observed in DII4 expression by endothelium within the tumor compared with endothelium at the invasive edge. In the TMAs, $73 \%$ (170 of 232, of which 47 were score 2 and 123 were score 1) of the adenocarcinomas but only $18 \%$ (7 of 38 , of which six were score 2 , and one was score 1) of in situ ductal carcinomas showed endothelial expression of DII4 (Figure 1, A-G). Differences between the TMAs and whole sections probably reflect sampling bias, due to core selection. TMAs of breast adenocarcinomas are generally constructed to preferentially represent malignant epithelium (the cell type of interest for most assays) and may, therefore, under represent associated endothelium. Alternatively, the small number of whole sections in this series $(n=10)$ may be insufficient to estimate accurately the proportion of tumors with endothelial expression of DII4. Nevertheless, scoring DII4 in TMA cores is a valid means of assessing microvessel density, equivalent to scoring endothelial staining in three randomly selected high power fields. Staining for CD31 in serial sections revealed that the proportion of endothelium staining for DIl4 varied considerably between tumors, from $0 \%$ to $100 \%$. This did not reflect vascular maturity or vessel size.

Nonlactating normal breast tissues ( $n=5$ breast reduction tissues; Figure 1, C and D) were negative for D\|l4 staining in all cell types. All cases of lactating non-neoplastic breast tissue $(n=5)$ were positive for DIl4 in all associated endothelium (irrespective of vessel maturity or size), but no other cell types (Supplemental Figure S2A, see http://ajp.amjpathol.org). Among the seven breast angiosarcomas, three showed strong cytoplasmic and membranous staining for DII4 in all malignant endothelial cells (Supplemental Figure S2B, see http://ajp. amjpathol.org). One breast angiosarcoma showed DII4 reactivity on $10 \%$ to $20 \%$ of malignant endothelial cells and three breast angiosarcomas were negative for DII4 expression. Of the malignant endothelial cells in the nine nonbreast angiosarcomas, four were negative (one of five skin and one of one vaginal), two were weakly positive (one of one liver and one of five skin), and three were strongly positive (one of one duodenal, one of one pleural, and one 
Table 1. Statistical Significance of Associations between Molecular and Categorical Clinical Variables

\begin{tabular}{|c|c|c|c|c|c|c|c|c|c|}
\hline Variable & Age & Grade & Size & $\begin{array}{l}\text { Nodal } \\
\text { status }\end{array}$ & ER & HER2 & Chemotherapy & Radiotherapy & $\begin{array}{l}\text { Hormonal } \\
\text { therapy }\end{array}$ \\
\hline DII4 & 2.7( & $10.5\left(0.03^{\star}\right)$ & $(0.26)$ & $0.2(0.90)$ & $12.6\left(0.002^{\dagger}\right)$ & $2.3(0.32)$ & $2.1(0.34)$ & $4.0(0.13)$ & $0.7(0.71)$ \\
\hline CD68 & 82) & 7.64 & $(0.08)$ & $11.9(0.003)$ & $1.7(0.4$ & $2.9(0.23)$ & $8.9(0.01)$ & $0.9(0.64)$ & $2.9(0.23)$ \\
\hline CD14 & $0.50(0.92)$ & $9.39(0.15)$ & $0.6(0.90)$ & $3.5(0.32)$ & $10.5\left(0.02^{\dagger}\right)$ & .30) & $5.44(0.14)$ & $2.28(0.52)$ & $1.60(0.66)$ \\
\hline Neutrophil & $6.8\left(0.03^{\star}\right)$ & $11.3\left(0.02^{\star}\right)$ & $(0.54)$ & .05) & $7.5\left(0.02^{+}\right)$ & $0.75)$ & $9.0(0.01)$ & $1.2(0.56)$ & $5.4(0.07)$ \\
\hline DC-SIGN & $2.3(0.32)$ & $6.6(0.16)$ & $2.0(0.37)$ & $0.7(0.71)$ & $0.3(0.86)$ & $0.85(0.65)$ & $0.4(0.80)$ & $6.7\left(0.04^{*}\right)$ & $0.3(0.86)$ \\
\hline CA9 & $4.99(0.17)$ & $12.9\left(<0.05^{\star}\right)$ & $5.2(0.16)$ & $3.5(0.32)$ & $24.9\left(<0.0001^{\dagger}\right)$ & $0.74(0.87)$ & $17.4(0.001)$ & $3.1(0.38)$ & $1.2(0.75)$ \\
\hline CD31 & $0.1(0.83)$ & $5.1(0.08)$ & $0.3(0.6)$ & $6.2(0.01)$ & $3.8(0.05)$ & $1.4(0.23)$ & $3.0(0.08)$ & $1.4(0.24)$ & $1.6(0.20)$ \\
\hline
\end{tabular}

Values presented as $\chi^{2}(P)$.

*These $P$ values are not significant following correction for multiple testing by the Benjamini and Hochberg false discovery rate controlling procedure with a cut-off $=0.05$. All associations are positive unless marked as ${ }^{\dagger}$ negative association.

of five skin) for DII4 expression. Macrophages and dendritic cells infiltrating breast adenocarcinomas showed membranous/cytoplasmic immunoreactivity for DII4 in approximately $10 \%$ of tumors (data not shown), consistent with published research. ${ }^{30}$ Although not specifically scored, $20 \%$ to $60 \%$ of tumor cells in approximately $5 \%$ of breast adenocarcinomas showed weak cytoplasmic/membranous expression of DII4 (data not shown), consistent with results in colon cancer. ${ }^{43,52}$

Immunohistochemistry for inflammatory cell markers selectively stained inflammatory cells with appropriate morphology. Cells positive for CD68, a panmyeloid marker, were observed infiltrating 73\% (140 of 192) of breast adenocarcinomas (Supplemental Figure S3A, see $h$ ttp:// ajp.amjpathol.org). The majority of these myeloid cells were $\mathrm{CD}_{14}{ }^{+}$macrophages (Supplemental Figure S3B, see http://ajp.amjpathol.org), observed in 46\% (102 of 222) of breast adenocarcinomas. A small minority of breast cancers showed infiltration by DC-SIGN positive immature myeloid dendritic cells $(6 \%, 13$ of 228 , Supplemental Figure S3C, see http://ajp.amjpathol.org) and/or neutrophils (16\%, 30 of 189; Supplemental Figure S3D, see http://ajp.amjpathol.org). Plasmacytoid dendritic cells $\left(\mathrm{CD} 123^{+}\right)$were only observed in one breast adenocarcinoma (of 230 cases stained). In this instance CD123+ cells were seen in a dense inflammatory cell infiltrate some distance from the breast cancer cells (Supplemental Figure S3E, see http://ajp.amjpathol.org). Cytoplasmic/ membranous CA9 expression was seen in approximately one third of breast adenocarcinomas (32\%, 49 of 151, Supplemental Figure S3F, see http://ajp.amjpathol.org). All tumor cells adjacent to foci of necrosis were positive for CA9, with a declining gradient of expression seen with increasing distance from the necrotic core. Occasionally CA9 expression was seen in tumor cells without adjacent necrosis. This may reflect transient or early hypoxia that has yet to progress to necrosis.

\section{Associations Between Molecular and Pathological Variables}

DII4 expression was positively associated with CD31 expression, reflecting microvessel density (Supplemental Table S2, see http://ajp.amjpathol.org). However, the presence of DII4 positive endothelial cells was not associated with hypoxia, as identified by CA9 expression, in this series of breast adenocarcinomas. DII4 endothelial expression was associated with the presence of CD68 and $\mathrm{CD} 14^{+}$inflammatory cells, but these associations were not statistically significant after correction for multiple testing. CD31 expression was positively associated with infiltration by CD68, CD14, and neutrophil elastase positive inflammatory cells. Expression of most inflammatory markers was positively associated with each other, suggesting that most inflammatory cell infiltrates contain a mixture of myeloid cells.

Although many correlations were significant, after correction for multiple testing, few associations were observed between molecular markers and clinicopathological data. Lymph node involvement by tumor was significantly associated with both $\operatorname{CD68}(P=0.003)$ and CD31 $(P=0.01)$ expression (Table 1$)$. ER status was negatively associated with DII4 $(P=0.002), \mathrm{CD} 14(P=$ $0.02)$, and neutrophil elastase $(P=0.02)$. The use of chemotherapy was significantly positively associated with CD68 $(P=0.01)$, neutrophil elastase $(P=0.01)$, and CA9 $(P=0.001)$.

\section{Survival}

In univariate analyses of overall survival, age $\geq 50$ years, tumor size $>2 \mathrm{~cm}$, lymph node involvement, Dll4 expression (score 2 vs. 0 or score 2 vs. 1), CD68 expression (score 2 vs. 0), DC-SIGN expression (score 1 or 2 vs. 0), and CD31 expression were all adverse prognostic factors (Table 2). In a Cox regression multivariate survival model (Table 3) that included all significant adverse prognostic factors from univariate analyses, only age $\geq 50$ years, lymph node involvement, and DII4 expression were significantly associated with overall survival $(P=0.004$, 0.01 , and 0.03 , respectively). These variables retain their significance when chemotherapy, radiotherapy, and hormonal therapy are included in the model $(P=0.015$, 0.006 , and 0.04 , respectively).

When Kaplan-Meier curves of overall survival were plotted for patients subgrouped according to DII4 expression, overlapping curves were seen for patients scoring 0 or 1 (Figure 2A). However, patients scoring 2 performed significantly worse, with a mean overall survival of 7.4 years ( $95 \%$ confidence interval, 5.7 to 9.0$)$, compared with 11.7 years (95\% confidence interval, 10.6 to 12.8 ) for score 1 and 11.4 years (95\% confidence interval, 10.1 to 
Table 2. Univariate Analysis of Overall Survival

\begin{tabular}{|c|c|c|c|c|c|}
\hline Variable & $n$ & Events & Hazard ratio & $95 \%$ confidence interval & $P^{\star}$ \\
\hline $\begin{array}{l}\text { Total } \\
\text { DII4 }\end{array}$ & 291 & 133 & & & \\
\hline 0 & 62 & 27 & 1.00 & & \\
\hline 1 & 123 & 48 & 0.90 & $0.56-1.44$ & 0.66 \\
\hline 2 & 47 & 32 & 2.29 & $1.37-3.82$ & 0.002 \\
\hline \multicolumn{6}{|l|}{ CD68 } \\
\hline 0 & 52 & 19 & 1.00 & & \\
\hline 1 & 77 & 32 & 1.19 & $0.68-2.10$ & 0.55 \\
\hline 2 & 63 & 39 & 2.00 & $1.16-3.47$ & 0.01 \\
\hline \multicolumn{6}{|l|}{ CD14 } \\
\hline 0 & 120 & 52 & 1.00 & & \\
\hline 1 & 49 & 24 & 1.16 & $0.72-1.89$ & 0.55 \\
\hline 2 & 39 & 16 & 0.90 & $0.52-1.58$ & 0.72 \\
\hline 3 & 14 & 8 & 1.61 & $0.77-3.40$ & 0.21 \\
\hline \multicolumn{6}{|l|}{ DC-SIGN } \\
\hline 0 & 215 & 91 & 1.00 & & \\
\hline 1,2 & 13 & 11 & 2.75 & $1.47-5.16$ & 0.002 \\
\hline \multicolumn{6}{|c|}{ Neutrophil elastase } \\
\hline 0 & 159 & 75 & 1.00 & & \\
\hline 1 & 19 & 8 & 1.01 & $0.49-2.10$ & 0.97 \\
\hline 2 & 11 & 6 & 1.18 & $0.51-2.70$ & 0.70 \\
\hline \multicolumn{6}{|l|}{ CA9 } \\
\hline 0 & 102 & 43 & 1.00 & & \\
\hline 1 & 25 & 9 & 0.88 & $0.43-1.81$ & 0.73 \\
\hline 2 & 11 & 6 & 1.65 & $0.70-3.87$ & 0.26 \\
\hline 3 & 13 & 6 & 1.26 & $0.54-2.98$ & 0.59 \\
\hline \multicolumn{6}{|l|}{ CD31 } \\
\hline 0 & 150 & 61 & 1.00 & & \\
\hline 1 & 102 & 56 & 1.50 & $1.05-2.16$ & 0.028 \\
\hline \multicolumn{6}{|l|}{ Age, yr } \\
\hline$<50$ & 80 & 20 & 1.00 & & \\
\hline$\geq 50$ & 211 & 113 & 2.74 & $1.70-4.41$ & $<0.0001$ \\
\hline \multicolumn{6}{|l|}{ Size, $\mathrm{cm}$} \\
\hline$\leq 2$ & 123 & 45 & 1.00 & & \\
\hline$>2$ & 167 & 87 & 1.73 & $1.21-2.49$ & 0.003 \\
\hline \multicolumn{6}{|l|}{ Lymph nodes } \\
\hline Uninvolved & 167 & 57 & 1.00 & & \\
\hline Involved & 119 & 73 & 2.43 & $1.72-3.44$ & $<0.0001$ \\
\hline \multicolumn{6}{|l|}{ Grade } \\
\hline 1 & 28 & 10 & 1.00 & & \\
\hline 2 & 129 & 60 & 1.26 & $0.65-2.47$ & 0.50 \\
\hline 3 & 94 & 47 & 1.52 & $0.77-3.01$ & 0.23 \\
\hline \multicolumn{6}{|l|}{ Histology } \\
\hline Ductal & 236 & 109 & 1.00 & & \\
\hline Lobular & 32 & 14 & 0.89 & $0.51-1.57$ & 0.70 \\
\hline Mixed & 14 & 7 & 1.13 & $0.52-2.42$ & 0.76 \\
\hline Other & 9 & 3 & 0.55 & $0.17-1.72$ & 0.30 \\
\hline \multicolumn{6}{|l|}{ ER } \\
\hline Negative & 65 & 33 & 1.00 & & \\
\hline Positive & 213 & 94 & 0.76 & $0.51-1.13$ & 0.17 \\
\hline \multicolumn{6}{|l|}{ HER2 } \\
\hline Negative & 226 & 101 & 1.00 & & \\
\hline Positive & 22 & 11 & 1.23 & $0.66-2.30$ & 0.51 \\
\hline \multicolumn{6}{|l|}{ Radiotherapy } \\
\hline No & 46 & 27 & 1.00 & & \\
\hline Yes & 245 & 106 & 0.67 & $0.44-1.02$ & 0.06 \\
\hline Chemotherapy & & & & & \\
\hline No & 228 & 104 & 1.00 & & \\
\hline Yes & 63 & 29 & 0.93 & $0.62-1.41$ & 0.74 \\
\hline Hormonal ther & & & & & \\
\hline No & 83 & 34 & 1.00 & & \\
\hline Yes & 208 & 99 & 0.72 & $0.48-1.07$ & 0.10 \\
\hline
\end{tabular}

${ }^{*}$ Cox regression analysis.

12.8) for score 0. (Note median survival times are not provided because they were not reached for score 0 or score 1 subgroups.) Stratifying these data by tumor size or nodal involvement yielded similar results (data not shown). In addition, expression of DII4 was a statistically significant variable in univariate $(P=0.01)$ and multivariate $(P=0.04)$ analyses of relapse-free survival (Figure 2B, Supplemental Tables S3 and S4, see http://ajp. 
Table 3. Multivariate Analysis of Overall Survival ( $n=156$ with 71 events)

\begin{tabular}{lcccc}
\hline \multicolumn{1}{c}{ Variable } & Hazard ratio & $95 \%$ confidence interval & Association with shorter survival & $P^{\star}$ \\
\hline Age & 3.00 & $1.41-6.39$ & In $\mathrm{yr}$ & 0.004 \\
Size & 1.55 & $0.88-2.72$ & Involved & 0.13 \\
Nodal status & 1.87 & $1.15-3.04$ & High expression & 0.01 \\
DII4 & 1.55 & $1.05-2.29$ & & 0.03 \\
CD68 & 1.17 & $0.80-1.70$ & \\
DC-SIGN & 1.33 & $0.83-2.15$ & 0.42 \\
CD31 & 1.34 & $0.79-2.28$ & 0.24 \\
\hline
\end{tabular}

${ }^{*}$ Cox regression analysis

amjpathol.org). Patients scoring 2 performed significantly worse, with a mean relapse-free survival of 7.1 years (95\% confidence interval, 5.3 to 8.9), compared with 11.1 years (95\% confidence interval, 9.9 to 12.2) for score 1 and 10.8 years (95\% confidence interval, 9.3 to 12.3 ) for score 0 .

\section{Discussion}

The addition of an anti-VEGF therapy (bevacizumab) to first-line taxane chemotherapy extends progressionfree survival in breast cancer, yet tumors eventually progress. ${ }^{10}$ Moreover, the addition of bevacizumab to chemotherapy has yet to demonstrate a benefit in overall survival in human breast cancer. ${ }^{10}$ Biomarkers are currently sought to identify bevacizumab resistance and targets for second-generation antiangiogenic drugs. DII4 is a Notch ligand that is selectively expressed by endothelium ${ }^{53}$ and is regulated by VEGF and hypoxia. ${ }^{46} \mathrm{Re}-$ cent data suggest that spatial regulation of DII4 signaling is involved in forming a functional vascular bed during tumor angiogenesis, ${ }^{17,18}$ and manipulating D\|l4-Notch signaling may inhibit tumor growth. ${ }^{17,18}$ Furthermore, there is growing evidence from model systems that DII4 expression may define a subset of tumors that are resis- tant to anti-VEGF therapies, ${ }^{28,29}$ and inhibition of DII4 may overcome bevacizumab resistance..$^{28,29}$ If validated in human cancer patients, these preclinical findings suggest that DII4 expression may have potential implications for the use of bevacizumab in breast cancer. Indeed characterizing DII4 expression may better inform appropriate indications for the use of an anti-DII4 antibody (Regeneron), which has recently entered phase I clinical trials. This is the first study to perform a detailed evaluation of DII4 expression in breast cancer and to relate DII4 expression to other known histological and prognostic markers.

DII4 expression was observed in the cytoplasm and membrane of the endothelium adjacent to invasive breast cancer and the malignant endothelium of angiosarcomas, but not nonlactating normal breast tissue. This is consistent with data from xenografts ${ }^{17}$ and in situ hybridization data for DII4 in bladder cancer ${ }^{45}$ and renal cell carcinoma. ${ }^{46,53}$ The lack of expression of Dll4 in the endothelial cells of normal nonlactating breast tissue is in keeping with the lack of VEGF expression and absence of hypoxia in nonlactating breast. ${ }^{54}$ Lactating breast showed high levels of DII4 positive vascular density, comparable with breast cancer, but lower than normal breast lobules. This is suggestive of physiological angiogenesis
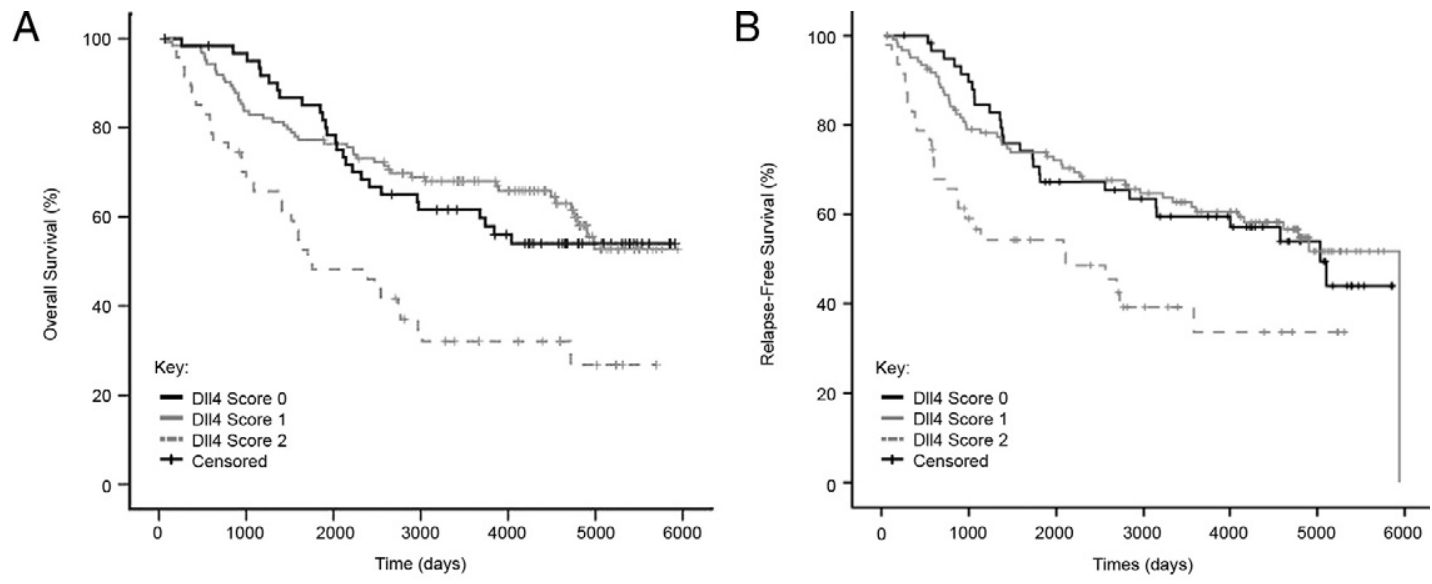

$\begin{array}{rlllllll}\text { Score 0, N } & 62 & 58 & 47 & 36 & 28 & 14 & 0 \\ \text { Events } & 0 & 2 & 13 & 23 & 26 & 27 & 27 \\ \text { Score 1, N } & 123 & 103 & 93 & 78 & 60 & 19 & 0 \\ \text { Events } & 0 & 20 & 29 & 38 & 41 & 48 & 48 \\ \text { Score 2, N } & 47 & 32 & 22 & 14 & 10 & 5 & 0 \\ \text { Events } & 0 & 14 & 24 & 30 & 31 & 32 & 32\end{array}$

$\begin{array}{lrlllllll}0 & \text { Score 0, N } & 61 & 52 & 37 & 32 & 25 & 12 & 0 \\ 27 & \text { Events } & 0 & 6 & 19 & 21 & 23 & 25 & 27 \\ 0 & \text { Score 1, N } & 122 & 93 & 81 & 66 & 54 & 15 & 0 \\ 48 & \text { Events } & 0 & 25 & 33 & 41 & 45 & 50 & 51 \\ 0 & \text { Score 2, N } & 47 & 26 & 19 & 10 & 6 & 3 & 0 \\ 32 & \text { Events } & 0 & 19 & 21 & 26 & 27 & 27 & 27\end{array}$

Figure 2. Kaplan-Meier overall survival (A) and relapse-free survival (B) curves for breast cancer patients subgrouped according to Dll4 expression is shown. Overall survival, Cox regression: score 2 vs. score 0; hazard ratio: 2.29 (95\% confidence interval, 1.37 to 3.82 ), $P=0.002$; score 2 vs. score 1 , hazard ratio: 2.54 (95\% confidence interval, 1.62 to 3.98), $P=0.00005$. Relapse-free survival, Cox regression: score 2 vs. score 0 ; hazard ratio: 2.03 (95\% confidence interval, 1.19 to 3.47 ), $P=0.01$; score 2 vs. score 1 , hazard ratio: 2.09 (95\% confidence interval, 1.30 to 3.36 ), $P=0.002$. 
in lactating breast, driven by VEGF expression in lactating glandular epithelium. ${ }^{55}$ These data suggest that strategies targeting DII4-Notch signaling may selectively affect the endothelium associated with breast cancer and angiosarcomas, but not endothelium associated with normal breast tissue. Although the expression of Dll4 by endothelium within lactating breast tissue may have implications for the use of anti-DII4 agents in pregnant women, such women are usually excluded from clinical trials. The heterogeneity in expression of DII4 in angiosarcomas is of interest because this tumor type could be considered for therapies targeting DII4. However, the numbers of cases in this series are too small to derive firm conclusions. It also demonstrates the need to select patients appropriately if new therapies are being developed.

The pathology studies showed several associations between the pathways. ER status was negatively associated with DII4, CD14, and neutrophil elastase. This is likely to be due to differing biology of $\mathrm{ER}^{+/-}$cancers, with a more hypoxic and proinflammatory phenotype in $\mathrm{ER}^{-}$ cancers. The use of chemotherapy was significantly positively associated with CD68, neutrophil elastase, and CA9. This reflects the strategy of treating more aggressive cancers. For example, infiltration by $\mathrm{CD}^{+} 8^{+}$myeloid cells was associated with nodal metastasis, adverse pathological stage and, therefore, an increased likelihood of receiving adjuvant chemotherapy. Similarly, CA9 and neutrophil elastase were associated with high-grade $\mathrm{ER}^{-}$cancers, which are more likely to receive adjuvant chemotherapy. CD31 expression was positively associated with infiltration by CD68, CD14, and neutrophil elastase positive cells. This suggests that inflammatory cells secrete proangiogenic factors and/or that tumors with a high vascular density provide more opportunities for inflammatory cells to infiltrate the stroma.

DII4 was a statistically significant prognostic factor in multivariate analyses that included established clinicopathological prognostic variables, treatment effects, and a well described panendothelial marker of microvessel density (CD31). One possible explanation for the adverse prognostic effect of DII4 in breast cancer is that DII4 expression is mechanistically associated with functional vascular beds, ${ }^{29}$ unlike CD31. Therefore, endothelial DII4 expression may be a closer surrogate marker of functional tumor angiogenesis (providing a medium for progression and metastasis) than microvessel density scores using panendothelial markers. Independent validation of these findings is imperative to confirm both the pattern of DII4 expression in breast adenocarcinomas and the prognostic significance of endothelial DII4 expression.

This is the first study to provide a comprehensive in situ assessment of inflammatory markers in human breast cancer. The data suggest that macrophages predominate in inflammatory infiltrates, with significant implications for angiogenesis in breast cancer, which has been attributed, in part, to the secretion of proangiogenic factors by macrophages. ${ }^{56}$ Consistent with previously published observations, expression of the myeloid cell marker $\mathrm{CD} 8^{57}$ was a weak adverse prognostic factor in univariate analyses of overall survival, but not relapsefree survival. Expression of DC-SIGN, an immature my- eloid dendritic cell marker, was also a significant prognostic factor in univariate analyses of overall survival, but not relapse-free survival. However, few tissues expressed DC-SIGN ( $n=13)$, and the statistical significance of these findings was not maintained in multivariate analyses. Studies looking at markers of more mature dendritic cells (CD1a and CD83) $)^{58,59}$ suggest that dendritic cell infiltration may be associated with a favorable prognosis, but these markers are likely to detect different dendritic cell subsets from the DC-SIGN positive population. ${ }^{37}$ Moreover, the sample size for certain subset analyses is $n<200$ ( $n=189$ for neutrophil elastase, $n=$ 192 for CD68, and $n=151$ for CA9) and analyses may, therefore, be underpowered to detect a statistically significant prognostic impact.

We have previously reported a statistically significant adverse prognostic impact of CA9 in a series of 103 breast cancer whole sections with 6.2-year median follow-up. ${ }^{60}$ This study failed to confirm CA9 as a statistically significant prognostic factor in overall survival or relapse free survival in 151 breast cancers represented in TMAs with 10-year median follow-up. The Kaplan-Meier survival curves for CA9 showed it to be a significant adverse prognostic factor in the first 8 years, but, by 16 years' follow-up, this statistical significance was lost (data not shown). Associations between CA9 and negative ER status, and CA9 and high grade morphology were statistically significant in both datasets.

In summary, DII4 is expressed in cancer associated endothelial cells, but not the endothelium adjacent to nonlactating normal breast epithelium. This study suggests that tumor endothelial expression of DII4 is a significant prognostic factor in early breast adenocarcinoma. These data may have clinical relevance because preclinical models ${ }^{28,29,61}$ suggest that assessing which patients express DII4 in their tumor endothelium may be critical in predicting benefit from anti-VEGF therapies.

\section{Acknowledgment}

We thank all clinicians and patients who provided material for this research.

\section{References}

1. Borgstrom P, Gold DP, Hillan KJ, Ferrara N: Importance of VEGF for breast cancer angiogenesis in vivo: implications from intravital microscopy of combination treatments with an anti-VEGF neutralizing monoclonal antibody and doxorubicin. Anticancer Res 1999, 19:4203-4214

2. Kim KJ, Li B, Winer J, Armanini M, Gillett N, Phillips HS, Ferrara N: Inhibition of vascular endothelial growth factor-induced angiogenesis suppresses tumour growth in vivo. Nature 1993, 362:841-844

3. Viacava P, Naccarato AG, Bocci G, Fanelli G, Aretini P, Lonobile A Evangelista G, Montruccoli G, Bevilacqua G: Angiogenesis and VEGF expression in pre-invasive lesions of the human breast. J Pathol 2004, 204:140-146

4. Petit AM, Rak J, Hung MC, Rockwell P, Goldstein N, Fendly B, Kerbe RS: Neutralizing antibodies against epidermal growth factor and ErbB-2/neu receptor tyrosine kinases down-regulate vascular endothelial growth factor production by tumor cells in vitro and in vivo: 
angiogenic implications for signal transduction therapy of solid tumors. Am J Pathol 1997, 151:1523-1530

5. Blancher C, Moore JW, Talks KL, Houlbrook S, Harris AL: Relationship of hypoxia-inducible factor (HIF)-1alpha and HIF-2alpha expression to vascular endothelial growth factor induction and hypoxia survival in human breast cancer cell lines. Cancer Res 2000, 60:7106-7113

6. Lin EY, Li JF, Gnatovskiy L, Deng Y, Zhu L, Grzesik DA, Qian H, Xue $X N$, Pollard JW: Macrophages regulate the angiogenic switch in a mouse model of breast cancer. Cancer Res 2006, 66:11238-11246

7. Relf M, LeJeune S, Scott PA, Fox S, Smith K, Leek R, Moghaddam A Whitehouse R, Bicknell R, Harris AL: Expression of the angiogenic factors vascular endothelial cell growth factor, acidic and basic fibroblast growth factor, tumor growth factor beta-1, platelet-derived endothelial cell growth factor, placenta growth factor, and pleiotrophin in human primary breast cancer and its relation to angiogenesis. Cancer Res 1997, 57:963-969

8. Hanrahan V, Currie M, Gunningham S, Morrin H, Scott P, Robinson B, Fox S: The angiogenic switch for vascular endothelial growth factor (VEGF)-A. VEGF-B, VEGF-C, and VEGF-D in the adenoma-carcinoma sequence during colorectal cancer progression. J Pathol 2003 200:183-194

9. Joyce JA, Laakkonen P, Bernasconi M, Bergers G, Ruoslahti E, Hanahan D: Stage-specific vascular markers revealed by phage display in a mouse model of pancreatic islet tumorigenesis. Cancer Cell 2003, 4:393-403

10. Miller K, Wang M, Gralow J, Dickler M, Cobleigh M, Perez EA, Shenkier T, Cella D, Davidson NE: Paclitaxel plus bevacizumab versus paclitaxel alone for metastatic breast cancer. N Engl J Med 2007 357:2666-2676

11. Miller KD, Chap LI, Holmes FA, Cobleigh MA, Marcom PK, Fehrenbacher L, Dickler M, Overmoyer BA, Reimann JD, Sing AP, Langmuir V Rugo HS: Randomized phase III trial of capecitabine compared with bevacizumab plus capecitabine in patients with previously treated metastatic breast cancer. J Clin Oncol 2005, 23:792-799

12. Grothey A, Hedrick EE, Mass RD, Sarkar S, Suzuki S, Ramanathan RK, Hurwitz HI, Goldberg RM, Sargent DJ: Response-independent survival benefit in metastatic colorectal cancer: a comparative analysis of N9741 and AVF2107. J Clin Oncol 2008, 26:183-189

13. Grothey A, Sugrue MM, Purdie DM, Dong W, Sargent D, Hedrick E, Kozloff M: Bevacizumab beyond first progression is associated with prolonged overall survival in metastatic colorectal cancer: results from a large observational cohort study (BRiTE). J Clin Oncol 2008 26:5326-5334

14. Ince WL, Jubb AM, Holden SN, Holmgren EB, Tobin P, Sridhar M, Hurwitz HI, Kabbinavar F, Novotny WF, Hillan KJ, Koeppen H: Association of k-ras, b-raf, and p53 status with the treatment effect of bevacizumab. J Natl Cancer Inst 2005, 97:981-989

15. Jubb AM, Hurwitz HI, Bai W, Holmgren EB, Tobin P, Guerrero AS, Kabbinavar F, Holden SN, Novotny WF, Frantz GD, Hillan KJ, Koeppen $\mathrm{H}$ : Impact of vascular endothelial growth factor-A expression, thrombospondin-2 expression, and microvessel density on the treatment effect of bevacizumab in metastatic colorectal cancer. J Clin Oncol 2006 24:217-227

16. Wedam SB, Low JA, Yang SX, Chow CK, Choyke P, Danforth D, Hewitt SM, Berman A, Steinberg SM, Liewehr DJ, Plehn J, Doshi A Thomasson D, McCarthy N, Koeppen H, Sherman M, Zujewski J, Camphausen K, Chen H, Swain SM: Antiangiogenic and antitumor effects of bevacizumab in patients with inflammatory and locally advanced breast cancer. J Clin Oncol 2006, 24:769-777

17. Noguera-Troise I, Daly C, Papadopoulos NJ, Coetzee S, Boland P Gale NW, Lin HC, Yancopoulos GD, Thurston G: Blockade of D\|l4 inhibits tumour growth by promoting non-productive angiogenesis. Nature 2006, 444:1032-1037

18. Ridgway J, Zhang G, Wu Y, Stawicki S, Liang WC, Chanthery $Y$ Kowalski J, Watts RJ, Callahan C, Kasman I, Singh M, Chien M, Tan C, Hongo JA, de Sauvage F, Plowman G, Yan M: Inhibition of DII4 signalling inhibits tumour growth by deregulating angiogenesis. Nature 2006, 444:1083-1087

19. Indraccolo S, Minuzzo S, Masiero M, Pusceddu I, Persano L, Moserle L, Reboldi A, Favaro E, Mecarozzi M, Di Mario G, Screpanti I, Ponzoni M, Doglioni C, Amadori A: Cross-talk between tumor and endothelial cells involving the Notch3-DII4 interaction marks escape from tumor dormancy. Cancer Res 2009, 69:1314-1323

20. Gale NW, Dominguez MG, Noguera I, Pan L, Hughes V, Valenzuela DM,
Murphy AJ, Adams NC, Lin HC, Holash J, Thurston G, Yancopoulos GD: Haploinsufficiency of delta-like 4 ligand results in embryonic lethality due to major defects in arterial and vascular development. Proc Natl Acad Sci USA 2004, 101:15949-15954

21. Sainson RC, Harris AL: Regulation of angiogenesis by homotypic and heterotypic notch signalling in endothelial cells and pericytes: from basic research to potential therapies. Angiogenesis 2008, 11:41-51

22. Duarte A, Hirashima M, Benedito R, Trindade A, Diniz P, Bekman E, Costa L, Henrique D, Rossant J: Dosage-sensitive requirement for mouse DII4 in artery development. Genes Dev 2004, 18:2474-2478

23. Hellstrom M, Phng LK, Hofmann JJ, Wallgard E, Coultas L, Lindblom P. Alva J, Nilsson AK, Karlsson L, Gaiano N, Yoon K, Rossant J, Iruela-Arispe ML, Kalen M, Gerhardt H, Betsholtz C: Dll4 signalling through Notch1 regulates formation of tip cells during angiogenesis. Nature 2007, 445:776-780

24. Siekmann AF, Lawson ND: Notch signalling limits angiogenic cell behavior in developing zebrafish arteries. Nature 2007, 445:781-784

25. Suchting S, Freitas C, le Noble F, Benedito R, Breant C, Duarte A Eichmann A: The Notch ligand Delta-like 4 negatively regulates endothelial tip cell formation and vessel branching. Proc Natl Acad Sci USA 2007, 104:3225-3230

26. Lobov IB, Renard RA, Papadopoulos N, Gale NW, Thurston G, Yancopoulos GD, Wiegand SJ: Delta-like ligand 4 (D\|l4) is induced by VEGF as a negative regulator of angiogenic sprouting. Proc Natl Acad Sci USA 2007, 104:3219-3224

27. Leslie JD, Ariza-McNaughton L, Bermange AL, McAdow R, Johnson SL, Lewis J: Endothelial signalling by the Notch ligand Delta-like 4 restricts angiogenesis. Development 2007, 134:839-844

28. Williams CK, Li JL, Murga M, Harris AL, Tosato G: Up-regulation of the Notch ligand Delta-like 4 inhibits VEGF-induced endothelial cell function. Blood 2006, 107:931-939

29. Li JL, Sainson RC, Shi W, Leek R, Harrington LS, Preusser M, Biswas S, Turley H, Heikamp E, Hainfellner JA, Harris AL: Delta-like 4 Notch ligand regulates tumor angiogenesis, improves tumor vascular function, and promotes tumor growth in vivo. Cancer Res 2007, 67:11244-11253

30. Fung E, Tang SM, Canner JP, Morishige K, Arboleda-Velasquez JF Cardoso AA, Carlesso N, Aster JC, Aikawa M: Delta-like 4 induces notch signaling in macrophages: implications for inflammation. Circulation 2007, 115:2948-2956

31. Shojaei F, Wu X, Malik AK, Zhong C, Baldwin ME, Schanz S, Fuh G Gerber HP, Ferrara N: Tumor refractoriness to anti-VEGF treatment is mediated by CD11b+Gr1+ myeloid cells. Nature Biotechnol 2007, 25:911-920

32. Shojaei F, Wu X, Qu X, Kowanetz M, Yu L, Tan M, Meng YG, Ferrara N: G-CSF-initiated myeloid cell mobilization and angiogenesis mediate tumor refractoriness to anti-VEGF therapy in mouse models. Proc Natl Acad Sci USA 2009, 106:6742-6747

33. Bubendorf L, Nocito A, Moch $\mathrm{H}$, Sauter G: Tissue microarray (TMA) technology: miniaturized pathology archives for high-throughput in situ studies. J Pathol 2001, 195:72-79

34. McShane LM, Altman DG, Sauerbrei W, Taube SE, Gion M, Clark GM: Reporting recommendations for tumor marker prognostic studies (REMARK). J Natl Cancer Inst 2005, 97:1180-1184

35. Poulsom R, Longcroft JM, Jeffery RE, Rogers LA, Steel JH: A robust method for isotopic riboprobe in situ hybridization to localize mRNAs in routine pathology specimens. Eur J Histochem 1998, 42:121-132

36. Williams CS, Leek RD, Robson AM, Banerji S, Prevo R, Harris AL, Jackson DG: Absence of lymphangiogenesis and intratumoural lymph vessels in human metastatic breast cancer. J Pathol 2003 200:195-206

37. Soilleux EJ, Morris LS, Leslie G, Chehimi J, Luo Q, Levroney E, Trowsdale J, Montaner LJ, Doms RW, Weissman D, Coleman N, Lee B: Constitutive and induced expression of DC-SIGN on dendritic cell and macrophage subpopulations in situ and in vitro. J Leukoc Biol 2002, 71:445-457

38. Pulford KA, Erber WN, Crick JA, Olsson I, Micklem KJ, Gatter KC Mason DY: Use of monoclonal antibody against human neutrophil elastase in normal and leukaemic myeloid cells. J Clin Pathol 1988 41:853-860

39. Soilleux EJ, Sarno EN, Hernandez MO, Moseley E, Horsley J, Lopes UG, Goddard MJ, Vowler SL, Coleman N, Shattock RJ, Sampaio EP: DC-SIGN association with the Th2 environment of lepromatous lesions: cause or effect? J Pathol 2006, 209:182-189

40. Loncaster JA, Harris AL, Davidson SE, Logue JP, Hunter RD, Wycoff CC, 
Pastorek J, Ratcliffe PJ, Stratford IJ, West CM: Carbonic anhydrase (CA IX) expression, a potential new intrinsic marker of hypoxia: correlations with tumor oxygen measurements and prognosis in locally advanced carcinoma of the cervix. Cancer Res 2001, 61:6394-6399

41. Pastorekova S, Zavadova Z, Kostal M, Babusikova O, Zavada J: A novel quasi-viral agent. MaTu, is a two-component system. Virology 1992, 187:620-626

42. Sun Q, Woodcock JM, Rapoport A, Stomski FC, Korpelainen EI, Bagley CJ, Goodall GJ, Smith WB, Gamble JR, Vadas MA, Lopez AF: Monoclonal antibody $7 \mathrm{G} 3$ recognizes the $\mathrm{N}$-terminal domain of the human interleukin-3 (IL-3) receptor alpha-chain and functions as a specific IL-3 receptor antagonist. Blood 1996, 87:83-92

43. Jubb AM, Turley H, Moeller HC, Steers G, Han C, Li JL, Leek R, Tan EY, Singh B, Mortensen NJ, Noguera-Troise I, Pezzella F, Gatter KC, Thurston G, Fox SB, Harris AL: Expression of delta-like ligand 4 (D\|4) and markers of hypoxia in colon cancer. $\mathrm{Br} J$ Cancer 2009, 101:1749-1757

44. Benjamini $Y$, Hochberg $Y$ : Controlling the false discovery rate: a practical and powerful approach to multiple testing. J R Statist Soc B 1995, 57:289-300

45. Patel NS, Dobbie MS, Rochester M, Steers G, Poulsom R, Le Monnier K, Cranston DW, Li JL, Harris AL: Up-regulation of endothelial deltalike 4 expression correlates with vessel maturation in bladder cancer. Clin Cancer Res 2006, 12:4836-4844

46. Patel NS, Li JL, Generali D, Poulsom R, Cranston DW, Harris AL: Up-regulation of delta-like 4 ligand in human tumor vasculature and the role of basal expression in endothelial cell function. Cancer Res 2005, 65:8690-8697

47. Gelb AB, Sudilovsky D, Wu CD, Weiss LM, Medeiros LJ: Appraisal of intratumoral microvessel density. MIB-1 score, DNA content, and p53 protein expression as prognostic indicators in patients with locally confined renal cell carcinoma. Cancer 1997, 80:1768-1775

48. Wykoff CC, Beasley NJ, Watson PH, Turner KJ, Pastorek J, Sibtain A, Wilson GD, Turley H, Talks KL, Maxwell PH, Pugh CW, Ratcliffe PJ, Harris AL: Hypoxia-inducible expression of tumor-associated carbonic anhydrases. Cancer Res 2000, 60:7075-7083

49. Graeme-Cook F, Bhan AK, Harris NL: Immunohistochemical characterization of intraepithelial and subepithelial mononuclear cells of the upper airways. Am J Pathol 1993, 143:1416-1422

50. Ramshaw AL, Parums DV: Combined immunohistochemical and immunofluorescence method to determine the phenotype of proliferating cell populations. J Clin Pathol 1992, 45:1015-1017

51. Pulford K, Banham AH, Lyne L, Jones M, Ippolito GC, Liu H, Tucker
PW, Roncador G, Lucas E, Ashe S, Stockwin L, Walewska R, Karran L, Gascoyne RD, Mason DY, Dyer MJ: The BCL11AXL transcription factor: its distribution in normal and malignant tissues and use as a marker for plasmacytoid dendritic cells. Leukemia 2006, 20:1439-1441

52. Hoey T, Yen WC, Axelrod F, Basi J, Donigian L, Dylla S, Fitch-Bruhns M, Lazetic S, Park IK, Sato A, Satyal S, Wang X, Clarke MF, Lewicki J, Gurney A: DLL4 blockade inhibits tumor growth and reduces tumor-initiating cell frequency. Cell Stem Cell 2009, 5:168-177

53. Mailhos C, Modlich U, Lewis J, Harris A, Bicknell R, Ish-Horowicz D: Delta4, an endothelial specific notch ligand expressed at sites of physiological and tumor angiogenesis. Differentiation 2001, 69:135-144

54. Guidi AJ, Schnitt SJ, Fischer L, Tognazzi K, Harris JR, Dvorak HF, Brown LF: Vascular permeability factor (vascular endothelial growth factor) expression and angiogenesis in patients with ductal carcinoma in situ of the breast. Cancer 1997, 80:1945-1953

55. Vuorela P, Andersson S, Carpen O, Ylikorkala O, Halmesmaki E: Unbound vascular endothelial growth factor and its receptors in breast, human milk, and newborn intestine. Am J Clin Nutr 2000, 72:1196-1201

56. Lewis JS, Landers RJ, Underwood JC, Harris AL, Lewis CE: Expression of vascular endothelial growth factor by macrophages is upregulated in poorly vascularized areas of breast carcinomas. J Pathol 2000, 192:150-158

57. Murri AM, Hilmy M, Bell J, Wilson C, McNicol AM, Lannigan A Doughty JC, McMillan DC: The relationship between the systemic inflammatory response, tumour proliferative activity. T-lymphocytic and macrophage infiltration, microvessel density, and survival in patients with primary operable breast cancer. $\mathrm{Br} J$ Cancer 2008, 99:1013-1019

58. Hillenbrand EE, Neville AM, Coventry BJ: Immunohistochemical localization of CD1a-positive putative dendritic cells in human breast tumours. Br J Cancer 1999, 79:940-944

59. Iwamoto M, Shinohara $H$, Miyamoto A, Okuzawa M, Mabuchi $H$, Nohara T, Gon G, Toyoda M, Tanigawa N: Prognostic value of tumorinfiltrating dendritic cells expressing CD83 in human breast carcinomas. Int J Cancer 2003, 104:92-97

60. Chia SK, Wykoff CC, Watson PH, Han C, Leek RD, Pastorek J, Gatter KC, Ratcliffe P, Harris AL: Prognostic significance of a novel hypoxiaregulated marker, carbonic anhydrase IX, in invasive breast carcinoma. J Clin Oncol 2001, 19:3660-3668

61. Li JL, Harris AL: Crosstalk of VEGF and Notch pathways in tumour angiogenesis: therapeutic implications. Front Biosci 2009, 14:30943110 